\title{
Mortality of Conotrachelus humeropictus in response to combined application of the nematode Steinernema brazilense and the fungus Beauveria bassiana
}

\author{
Mortalidade de Conotrachelus humeropictus pela aplicação combinada do nematoide \\ Steinernema brazilense com o fungo entomopatogênico Beauveria bassiana
}

\author{
Lucas Detogni Simi ${ }^{1 *}$, Luís Garrigós Leite ${ }^{2}$, Olzeno Trevisan², José Nilton Medeiros Costa ${ }^{3}$, \\ Leandro Ezequiel Oliveira ${ }^{4}$, Fabio Silber Schmidt ${ }^{5}$, Roselaine Nunes da Silva Bueno ${ }^{2}$, Antonio Batista Filho ${ }^{2}$
}

\begin{abstract}
The fruit borer Conotrachelus humeropictus is one of the most important pests of the cupuaçu crop, and can promote yield losses of around 50\%. The present study involved the selection of Beauveria bassiana isolates on Conotrachelus psidii larvae, which was used as test insect due to its taxonomic closeness to $C$. humeropictus. In order to assess their interaction using combined application, we studied the ability of the nematode to carry conidia of $B$. bassiana and Metarhizium anisopliae to soil layers. This study also aimed to establish a biological control method for cupuaçu borer with the use of the fungus $B$. bassiana at $10 \mathrm{~kg} / \mathrm{ha}$ and the entomopathogenic nematode Steinernema brazilense at 1, 3, 9, and $27 \mathrm{IJ} / \mathrm{cm}^{2}$, applied as single and combined treatments. In the selection of $B$. bassiana strains for $C$. psidii, the IBCB 276 and IBCB 165 isolates were the most promising ones, causing 86 and $84 \%$ mortality, respectively. The IBCB 276 strain was applied in the field to control $C$. humeropictus. In the study of carriage of conidia in soil, the nematode $S$. brazilense was found to be capable of carrying conidia of $B$. bassiana to deep 7 to $10 \mathrm{~cm}$ soil layers. This was not observed with $M$. anisopliae, found only in the topsoil. In field trials against $C$. humeropictus larvae, $B$. bassiana promoted $15.6 \%$ mortality. The nematode promoted $60.0 \%$ mortality at the highest concentration used, and their combined use with $B$. bassiana $(10 \mathrm{~kg} / \mathrm{ha})$ increased mortality to $65.6 \%$, with an additive interaction observed between the two entomopathogens.
\end{abstract}

KEYWORDS: biological control; microbial control; interaction; combined use.
RESUMO: A broca-do-cupuaçu, Conotrachelus humeropictus, é uma das principais pragas da cultura, podendo ocasionar perdas de $50 \%$ na produção. O presente trabalho envolveu uma seleção prévia de isolados de Beauveria bassiana em larvas de Conotrachelus psidii, utilizado como inseto teste por ser próximo taxonomicamente à C. humeropictus. Com o objetivo de avaliar causa-efeitos da interação na aplicação combinada, foi estudada a capacidade do nematoide carrear conídios de B. bassiana e Metarhizium anisopliae pelas camadas de solo. O trabalho também objetivou avaliar o controle biológico da broca-do-cupuaçu, através do uso do fungo $B$. bassiana $10 \mathrm{~kg} / \mathrm{ha}$, e do nematoide entomopatogênico Steinernema brazilense 1 , $3,9 \mathrm{e} 27 \mathrm{JI} / \mathrm{cm}^{2}$, aplicados em tratamentos isolados e em combinaçáo. Na seleção de isolados de B. bassiana para C. psidii, os isolados IBCB 276 e IBCB 165 foram os mais promissores, causando, respectivamente, 86 e $84 \%$ de mortalidade confirmada. $\mathrm{O}$ isolado IBCB 276 foi aplicado em campo para controlar C. humeropictus. No estudo de carreamento de conídios, o nematoide $S$. brazilense foi capaz de carrear conídios de B. bassiana para a camada de 7 a $10 \mathrm{~cm}$ de profundidade no solo. A mesma ação não foi observada com $M$. anisopliae, encontrado somente na camada superficial do solo. Nos ensaios de campo contra C. humeropictus, B. bassiana promoveu $15,6 \%$ de mortalidade. O nematoide promoveu $60,0 \%$ de mortalidade na maior concentração utilizada e, na combinação dessa concentração do NEP com B. bassiana (10 kg/ha), a mortalidade atingiu 65,6\%, observando-se interação aditiva entre os dois entomopatógenos.

PALAVRAS-CHAVE: controle biológico; controle microbiano; interação; uso combinado.

\footnotetext{
'Universidade Estadual Paulista “Júlio de Mesquita Filho”, Campus de Botucatu - Botucatu (SP), Brazil ${ }^{2}$ Instituto Biológico - São Paulo (SP), Brazil

${ }^{3}$ EMBRAPA Rondônia, CEPLAC - Comissão Executiva do Plano da Lavoura Cacaueira - Porto Velho (RO), Brazil ${ }^{4}$ CEPLAC - Comissão Executiva do Plano da Lavoura Cacaueira - Belém (PA), Brazil ${ }^{5}$ Bio Controle - Métodos de controle de pragas Ltda - Indaiatuba (SP), Brazil

*Corresponding author: lucasdsimi@yahoo.com.br Received on: 02/04/2016. Accepted on: 03/12/2018
}

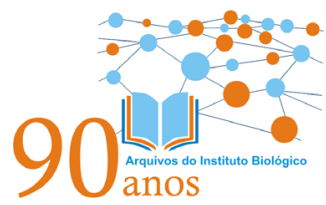




\section{INTRODUCTION}

Larvae of the insect Conotrachelus humeropictus (Fiedler, 1940) (Coleoptera: Dryophthoridae) attack cocoa and cupuaçu fruits, causing damage that depreciates the product and can result in production losses of up to 50\% (LAKER; TREVISAN, 1992). In Brazil, this pest occurs in the Amazon Region, particularly in the states of Rondônia, Acre, Amazonas, Mato Grosso, and Santarém in the state of Pará.

During its life cycle, the fourth instar larvae remain in the soil for 2-3 months. During this period, biological control should be investigated through the inundative application of nematodes and entomopathogenic fungi, which are important soil pest controllers.

The nematodes Steinernema and Heterorhabditis (Rhabditida: Steinernematidae; Heterorhabditidae) act against a great diversity of species of insects, mainly those that inhabit the soil. They differ from other entomopathogens by establishing a mutual association with bacteria of the genus Xenorhabdus spp. and Photorhabdus spp. These nematodes undergo an immature stage of free life known as the infective juvenile (IJ) stage, during which they live in the soil and are able to enter the host through natural openings (mouth, anus, and spiracles), and in the case of the Heterorhabditidae, through the cuticle. They release symbiotic bacterium into the hemocele of the insect, leading to disease and host death between 24 and 72 hours. The nematode feeds on bacteria and host tissue, reproducing for 2-3 generations. With the exhaustion of food, IJ emerge from the host and search for a new insect to infect (KAYA; GAUGLER, 1993; CAMPBELL; KAYA, 2000; DOWDS; PETERS, 2002).

Entomopathogenic fungi are broad-spectrum pathogens, which are capable of infecting insects that live in the aerial part of plants and in the soil, and are able to cause natural epizootics. They can infect hosts at different stages of development, such as eggs, pupae, and adults; this characteristic is very desirable and peculiar to this group (ALVES, 1998).

The combined use of two entomopathogens can generate higher levels of target pest control, since the mortality of the insect is higher than that obtained by the use of each agent applied alone, with evidence of synergism observed sometimes. The combination of nematodes and Paenibacillus popilliae (Dutky, 1940) or Bacillus thuringiensis (Berliner, 1911) strain Buibui, resulted in a significant increase in mortality of Cyclocephala hirta larvae (Coleoptera: Scarabaeidae) when compared to each agent tested in isolation (THURSTON et al., 1994; KOPPENHÖFER; KAYA, 1997). This was also observed when the fungus Metarhizium anisopliae (Metschnikoff, 1879) Sorokin, 1883 was evaluated in combination with the nematode $H$. bacteriophora against the grass pest Hoplia philanthus (Füessly, 1775) (Coleoptera: Scarabaeidae), promoting control of up to $95 \%$ under field conditions (ANSARI et al., 2006).
The mechanisms responsible for these synergistic interactions are poorly understood, but an agent may cause stress or alter the behavior of the target insect, making it more susceptible to the other entomopathogen (ANSARI et al., 2004). Insects exposed to B. thuringiensis feed less, and become weaker and more vulnerable to entomopathogenic nematodes (KOPPENHÖFER; KAYA, 1997).

The combined use of fungi and entomopathogenic nematodes in the control of coleopterans has been shown in increase mortality, providing a potential technique that can be used to promote the greater control of these pest insects (ANSARI et al., 2008; SHAOHUI et al., 2014; SHAPIRO-ILAN, 2004). Thus, the objective of this study was to evaluate the virulence of different isolates of the fungus Beauveria bassiana (Balsamo) Vuillemin, 1912 on guava weevil larvae, Conotrachelus psidii (Marshall, 1922) (Coleoptera: Dryophthoridae), and the effect of combined S. brazilense with the fungi B. bassiana and $M$. anisopliae, in the carriage of conidia in the soil and on the mortality of $C$. humeropictus larvae.

\section{MATERIAL AND METHODS}

\section{Selection of B. bassiana isolates for $C$. psidii}

The effects of fifteen isolates of $B$. bassiana and water (control) on larvae of the guava weevil, $C$. psidii, were evaluated in order to select the most virulent isolate to be used in the field against the fruit borer, $C$. humeropictus. The guava weevil was used in this test because it was easy to obtain in the regions near Campinas, São Paulo, and in the guavas of Valinhos, São Paulo, and because of the difficulty of obtaining $C$. humeropictus, which is found only in the Amazon region. The guava weevil, $C$. psidii, was then used, which is the taxonomically closest insect and was easily obtained from guava fruits collected from orchards in the city of Valinhos, São Paulo, Brazil. The fruits were manually opened and the fourth-instar larvae were collected and conditioned in plastic trays of $38 \times 28 \times 6.5 \mathrm{~cm}$ containing $4.400 \mathrm{~g}$ of fine sand with $10 \%$ moisture, and kept at $16 \pm 2^{\circ} \mathrm{C}$.

Fungus isolates were obtained from the "Oldemar Cardim Abreu" Entomopathogenic Collection, maintained at the Experimental Center of the Instituto Biológico, Campinas, São Paulo (Table 1). The isolates were reinvigorated in Galleria mellonella (Linnaeus, 1758) (Lepidoptera: Pyralidae) larvae, and then cultivated in plates containing potato-dextrose-agar (PDA) and incubated for 20 days in a B.O.D. incubator at $25 \pm 1^{\circ} \mathrm{C}$ with a 12 -hour photoperiod. After 20 days of culture, the conidia on the surface of the colonies were scraped and transferred to tubes containing a solution of $0.1 \%$ Tween $80^{\circledast}$. 
The suspension was standardized to a concentration of $1.0 \times 10^{7}$ conidia/mL, with viability above $90 \%$.

The larvae were immersed in fungal suspension for 60 seconds and transferred to $1,000 \mathrm{~mL}$ plastic pots containing $1,100 \mathrm{~g}$ of fine sand, moistened at $10 \%$. Ten C. psidii larvae were placed into each pot, which were then capped. The pots were conditioned in an air-conditioned room at $25 \pm 1^{\circ} \mathrm{C}$ with photoperiod for 12 hours. Larval mortality was evaluated after 7 days. Each treatment involved five replicates; each replicate included a plastic pot with $300 \mathrm{~g}$ of washed fine sand, moistened at $10 \%$.

A completely randomized design was used. Analysis of variance in the data (F-test) was performed, and the means were compared using the Tukey test at $5 \%$ probability. SAS software, version 9.0, was used to analyze the data (SAS INSTITUTE, 2000).

Table 1. Beauveria bassiana isolates used for selection against the fruit borer, Conotrachelus psidii.

\begin{tabular}{|c|c|c|c|}
\hline Isolate & Host & Date & $\begin{array}{l}\text { Municipality of } \\
\text { collection }\end{array}$ \\
\hline $\begin{array}{l}\text { IBCB } \\
07\end{array}$ & Soil & 08/01/98 & Cascavel-PR \\
\hline $\begin{array}{l}\text { IBCB } \\
28\end{array}$ & $\begin{array}{l}\text { Cosmopolites } \\
\text { sordidus }\end{array}$ & $02 / 01 / 86$ & Miracatu-SP \\
\hline $\begin{array}{l}\text { IBCB } \\
31\end{array}$ & Nezara viridula & 03/01/86 & Piracicaba-SP \\
\hline $\begin{array}{l}\text { IBCB } \\
35\end{array}$ & $\begin{array}{l}\text { Cosmopolites } \\
\text { sordidus }\end{array}$ & 03/01/86 & Cruz das Almas-BA \\
\hline $\begin{array}{l}\text { IBCB } \\
67\end{array}$ & $\begin{array}{l}\text { Hypothenemus } \\
\text { hampei }\end{array}$ & 09/01/86 & S. J. do Rio Pardo-SP \\
\hline $\begin{array}{l}\text { IBCB } \\
81\end{array}$ & Soil & 07/01/99 & Cascavel-PR \\
\hline $\begin{array}{l}\text { IBCB } \\
82\end{array}$ & $\begin{array}{l}\text { Cosmopolites } \\
\text { sordidus }\end{array}$ & $01 / 01 / 89$ & Goiânia-GO \\
\hline $\begin{array}{l}\text { IBCB } \\
102\end{array}$ & Soil & $01 / 01 / 99$ & Cosmópolis SP \\
\hline $\begin{array}{l}\text { IBCB } \\
165\end{array}$ & Soil & 05/01/99 & Espigão Azul-PR \\
\hline $\begin{array}{l}\text { IBCB } \\
170\end{array}$ & Soil & 05/01/99 & Iracemápolis-SP \\
\hline $\begin{array}{l}\text { IBCB } \\
206\end{array}$ & Soil & 05/01/99 & Ribeirão Preto-SP \\
\hline $\begin{array}{l}\text { IBCB } \\
239\end{array}$ & $\begin{array}{l}\text { Hypothenemus } \\
\text { hampei }\end{array}$ & 06/01/99 & Campinas-SP \\
\hline $\begin{array}{l}\text { IBCB } \\
241\end{array}$ & $\begin{array}{c}\text { Oryzophagus } \\
\text { oryzae }\end{array}$ & 06/01/99 & Pindamonhangaba-SP \\
\hline $\begin{array}{l}\text { IBCB } \\
246\end{array}$ & $\begin{array}{l}\text { Hypothenemus } \\
\text { hampei }\end{array}$ & 06/01/99 & Taubaté-SP \\
\hline $\begin{array}{l}\text { IBCB } \\
276\end{array}$ & Soil & 06/01/99 & Ribeirão Preto-SP \\
\hline
\end{tabular}

\section{Carriage of conidia in soil}

In this test, the ability of nematodes to carry conidia to deep layers of the soil was investigated in order to increase the likelihood of contact between the fungus and the host.

The isolates IBCB 170 of $B$. bassiana and IBCB 383 of $M$. anisopliae were used as they had been previously selected. The isolates were cultivated in Petri dishes containing the PDA culture and kept in an air-conditioned chamber at $25 \pm 1{ }^{\circ} \mathrm{C}$ with a 12-hour photoperiod for 20 days.

The nematode $S$. brazilense IBCB n6 was produced in vitro in the Laboratory of Biological Control by the sponge process, as described by BEDDING (1981). This isolate is preserved in stock culture at the Entomopathogenic Collection of the Instituto Biológico.

Six treatments were established:

1. B. bassiana $-1.0 \times 10^{8}$ conidia $/ \mathrm{mL}$;

2. M. anisopliae $-1.0 \times 10^{8}$ conidia $/ \mathrm{mL}$;

3. Steinernema brazilense $-3 \mathrm{IJ} / \mathrm{cm}^{2}$, equivalent to $50 \mathrm{IJ} /$ insect;

4. B. bassiana $1.0 \times 10^{8}$ conidia $/ \mathrm{mL}+S$. brazilense $3 \mathrm{IJ} / \mathrm{cm}^{2}(50 \mathrm{IJ} /$ insect $)$;

5. M. anisopliae $-1.0 \times 10^{8}$ conidia $/ \mathrm{mL}+$ S. brazilense $3 \mathrm{IJ} / \mathrm{cm}^{2}$ (50 IJ/insect); and

6. Control (water).

Three replicates were used for each treatment; each replicate included a $700 \mathrm{~mL}$ plastic cup filled with $1,000 \mathrm{~g}$ of fine sand washed, sterilized, and moistened at $10 \%$ with autoclaved distilled water. The cups were marked externally in layers at $0-4,4-7$, and $7-10 \mathrm{~cm}$ below the soil surface. Five G. mellonella larvae were placed in the bottom of each cup, grouped in a small cage prepared with a metal screen to drive the nematodes towards the deeper soil layer.

A pipette was used to inoculate $3 \mathrm{~mL}$ of the suspension on the soil surface. The cups were kept in an air-conditioned room at $25 \pm 1^{\circ} \mathrm{C}$ with a 12 -hour photoperiod. Seven-days after application, each cup was cut at the markings with the aid of an overheated scalpel, to allow the separation of soil layers to evaluate the concentration of conidia at the different depths.

A $1 \mathrm{~g}$ soil sample was taken from each of the three soil layers and placed in a tube containing $10 \mathrm{~mL} 0.1 \%$ Tween $80^{\oplus}$. A 1:9 dilution was prepared, and $0.1 \mathrm{~mL}$ was taken and placed on a plate containing the PDA culture with antibiotic Pentabiotic ${ }^{\circledast}$ to prevent bacterial growth. Each sample was inoculated three times. After 4 days of cultivation in a chamber $\left(25 \pm 1^{\circ} \mathrm{C}\right.$, 12-hour photoperiod), colony-forming units (CFU) were counted.

Larval mortality was evaluated when soil samples were obtained from the deepest soil layer. For this, the metal cages were opened and the insects were evaluated for mortality. The dead insects were transferred to Petri dishes containing two units of circular filter paper moistened in their bases for observation after 5 days for the emergence of IJ or sporulation of the fungus. 
A completely randomized design was used and the data were submitted to analysis of variance through the F-test. The experiment was conducted four times and each was analyzed separately. The average $\mathrm{CFU}$ and mortality rate of G. mellonella were compared by the Duncan test at 5\% probability. SAS software version 9.0 was used to analyze the data.

\section{Effect of S. brazilense and $B$. bassiana on the mortality of $C$. humeropictus in the field}

Field trials were conducted to evaluate the effect of the nematode $S$. brazilense combined with the fungus $B$. bassiana at different concentrations, at a dose of $10 \mathrm{~kg} / \mathrm{ha}$, with the purpose of controlling the fruit borer.

The work was carried out in March 2013 in an area of sandy-loam soil with organic cupuaçu plantation located at the CEPLAC (Comissão Executiva do Plano da Lavoura Cacaueira) Experimental Station in Ouro Preto do Oeste, Rondônia. Ten treatments were stablished: $S$. brazilense at concentrations of $1,3,9$, and $27 \mathrm{IJ} / \mathrm{cm}^{2}$, the nematode at the same doses combined with the fungus $B$. bassiana IBCB $276(10 \mathrm{~kg} / \mathrm{ha})$, the fungus tested alone at the same dose, and the control (water).

Three replicates were distributed in randomized blocks for each treatment. Each replicate was represented by a $1 \mathrm{~m}^{2}$ plot containing three envelopes $(17 \times 13 \mathrm{~cm})$ prepared with an anti-aphid mesh screen; envelopes were partially buried and randomly distributed with their upper parts open. The envelopes were half-filled with $2 \mathrm{~kg}$ of soil from the same site along with a further five larvae of $C$. humeropictus. Then, the upper openings of the envelopes were closed with a stapler and the nematode was distributed in the plot with the aid of an Erlenmeyer flask, and $100 \mathrm{~mL}$ of the suspension was added to each plot.

The evaluation was performed 21 days after application by counting live and dead insects inside the envelopes.

The experiment was repeated three times following exactly the same methodology. The means were transformed into arc$\sin \sqrt{ }(x / 100)$ and the data were analyzed by the Duncan test at $5 \%$ probability.

\section{RESULTS AND DISCUSSION}

\section{Selection of B. bassiana isolates for $C$. psidii}

The B. bassiana isolates presented variable virulence for $C$. psidii larvae, with mortality rates of 8 to $86 \%$ observed. The highest
Table 2. Mortality of Conotrachelus psidii larvae by Beauveria bassiana isolates, standardized to $1.0 \times 10^{7}$ conidia $/ \mathrm{mL}$.

\begin{tabular}{|c|c|c|}
\hline Isolate & Mortality + S.E. (\%) & Original host \\
\hline IBCB 276 & $86.00 \pm 0.40 a$ & Soil \\
\hline IBCB 165 & $84.00 \pm 0.60 \mathrm{a}$ & Soil \\
\hline IBCB 241 & $78.00 \pm 0.73 a b$ & Oryzophagus oryzae \\
\hline IBCB 067 & $72.00 \pm 1.06 \mathrm{abc}$ & $\begin{array}{c}\text { Hypothenemus } \\
\text { hampei }\end{array}$ \\
\hline IBCB 206 & $66.00 \pm 0.81 \mathrm{abcd}$ & Soil \\
\hline IBCB 081 & $64.00 \pm 0.51 \mathrm{abcd}$ & Soil \\
\hline IBCB 239 & $58.00 \pm 0.97$ abcde & $\begin{array}{c}\text { Hypothenemus } \\
\text { hampei }\end{array}$ \\
\hline IBCB 028 & $52.00 \pm 0.66$ abcdef & $\begin{array}{c}\text { Cosmopolites } \\
\text { sordidus }\end{array}$ \\
\hline IBCB 170 & $46.00 \pm 1.12$ bcdef & Soil \\
\hline IBCB 007 & $38.00 \pm 0.73$ cdefgh & Soil \\
\hline IBCB 035 & $36.00 \pm 0.60$ defgh & $\begin{array}{c}\text { Cosmopolites } \\
\text { sordidus }\end{array}$ \\
\hline IBCB 246 & $28.00 \pm 0.73$ efghi & $\begin{array}{c}\text { Hypothenemus } \\
\text { hampei }\end{array}$ \\
\hline IBCB 102 & $22.00 \pm 0.37 \mathrm{fghi}$ & Soil \\
\hline IBCB 082 & $14.00 \pm 0.51 \mathrm{ghi}$ & $\begin{array}{c}\text { Cosmopolites } \\
\text { sordidus }\end{array}$ \\
\hline IBCB 031 & $08.00 \pm 0.37 \mathrm{ji}$ & Nezara viridula \\
\hline Control & $00.00 \pm 0.00 i$ & - \\
\hline
\end{tabular}

Means followed by the same letter do not differ from each other by the Tukey test at $5 \%$ probability. Original mortality means, but analysis data transformed into $\arcsin \sqrt{(x / 100)}$. C.V. $(\%)=23.70$;

$\mathrm{F}=14.39^{* *}$. S.E.: Standard error.

${ }^{* *}$ Significant at $1 \%$ probability.

mortality rates were caused by the IBCB 276 and IBCB 165 isolates, which promoted C. psidii larvae mortality of 86 and $84 \%$, respectively. However, these rates were not significantly different from that observed with the other six isolates: IBCB 241 (78\% mortality), IBCB 067 (72\%), IBCB 206 (66\%), IBCB 081 (64\%), IBCB 239 (58\%), and IBCB 28 (58\%) $(\mathrm{F}=14.39 ; \mathrm{p}<0.0001)$ (Table 2).

The isolate IBCB 276 was selected and combined with the nematode $S$. brazilense to control the fruit borer $C$. humeropictus under field conditions.

\section{Carriage of conidia in soil}

Evaluation of larval mortality in the deepest soil layer revealed that $S$. brazilense alone and in combination with B. bassiana caused $100 \%$ mortality, whereas isolated applications of B. bassiana and M. anisopliae did not lead to death. For the S. brazilense + B. bassiana treatment, the mortality was induced by the nematode. No mortality was observed in the control group. 
Similar results were observed by ACEVEDO et al. (2007) when evaluating the simultaneous inoculation of fungi and nematodes in larvae of Diatraea saccharalis (Fabricius, 1794) (Lepidoptera: Crambidae). Mortality was due exclusively to the nematodes, which presented significantly lower lethal times $\left(\mathrm{LT}_{100}\right)$. However, the number of IJs per larvae was lower with the combined treatments.

Evaluation of the carriage of $B$. bassiana conidia when applied alone in the four trials revealed a higher number of CFU in the $0-4 \mathrm{~cm}$ layer of soil. Conversely, when the fungus was applied in combination with $S$. brazilense, conidia were found in the deeper layers of the soil $(4-7$ and $7-10 \mathrm{~cm})$, as shown in Figure 1. No CFU were found following treatment with $S$. brazilense when tested alone and in the control.

In the first and second trials, the treatment with $B$. bassiana resulted in a high number of CFU in the $0-4 \mathrm{~cm}$ soil layer, differing significantly from that in the other layers. For B. bassiana + S. brazilense, the $7-10 \mathrm{~cm}$ layer contained the highest number of CFU, differing significantly from that in the other layers. In the third and fourth trials, similar results were observed when $B$. bassiana was applied alone, with a higher number of CFU in the $0-4 \mathrm{~cm}$ layer, and differed statistically from that observed in the other layers. However, following treatment with $B$. bassiana $+S$. brazilense, the greatest number of CFU was found in shallower soil compared with the first trials, mostly in the $4-7 \mathrm{~cm}$ layers, differing statistically from the other layers (Trial 1: $F=102.06 ; p<0.001$; Trial 2: $F=18.06 ; p<0.0001$; Trial 3: $F=43.46 ; p<0.0001$; Trial 4: $\mathrm{F}=59.80 ; \mathrm{p}<0.0001 ;$ Fig. 1$)$.

In the conidia carriage trials of $M$. anisopliae, the fungus was not present in the control, nor in the treatment where nematode was applied alone. In the four experiments in which $M$. anisopliae was applied alone and in combination with $S$. brazilense, the fungus was found only in the first soil layer $(0-4 \mathrm{~cm})$, which differed statistically from the deeper layers $(4-7$ and $7-10 \mathrm{~cm})$ in relation to the number of CFUs (Fig. 2).

For the $S$. brazilense $+M$. anisopliae combination, the fungus was not present in the deeper layers of soil, and was only found in the $0-4 \mathrm{~cm}$ layer, as observed when $M$. anisopliae was applied alone (Trial 1: $\mathrm{F}=9.69 ; \mathrm{p}<0.001$; Trial 2: $\mathrm{F}=29.29 ; \mathrm{p}<0.0001$; Trial 3: $\mathrm{F}=24.60 ; \mathrm{p}<0.0001$; Trial 4: $\mathrm{F}=26.71 ; \mathrm{p}<0.0001 ;$ Fig. 2).

Conidia can be carried into the soil; however, their mobility is influenced by soil texture and organic matter. Sandy soils with low organic matter retain less conidia in relation to more clayey soils with a higher content of organic matter (IGNOFFO et al., 1977; STOREY; GARDNER, 1988).

Sandy soil may allow greater movement of some conidia because of its greater porosity. In tests performed by IGNOFFO et al. (1977), conidia of the fungus Nomuraea rileyi moved to depths of $10.5 \mathrm{~cm}$ in sandy soil after $16.25 \mathrm{~cm}$ rainfall.
Trial 1

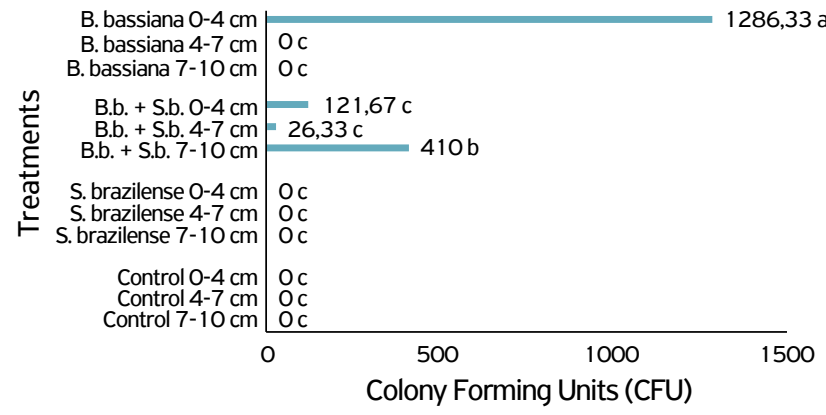

Trial 3

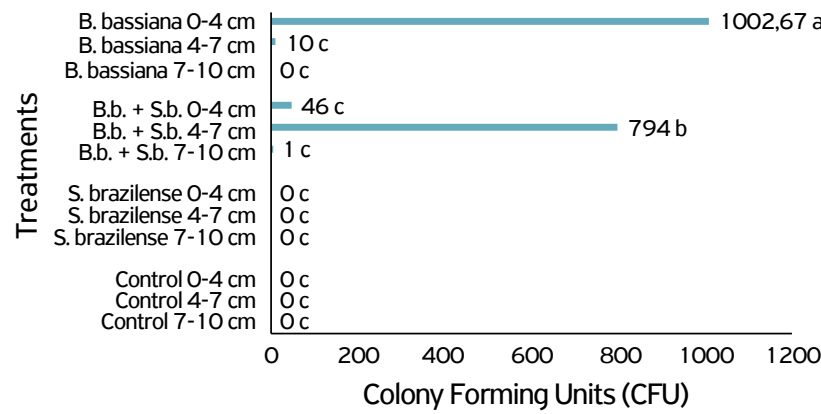

\section{Trial 2}

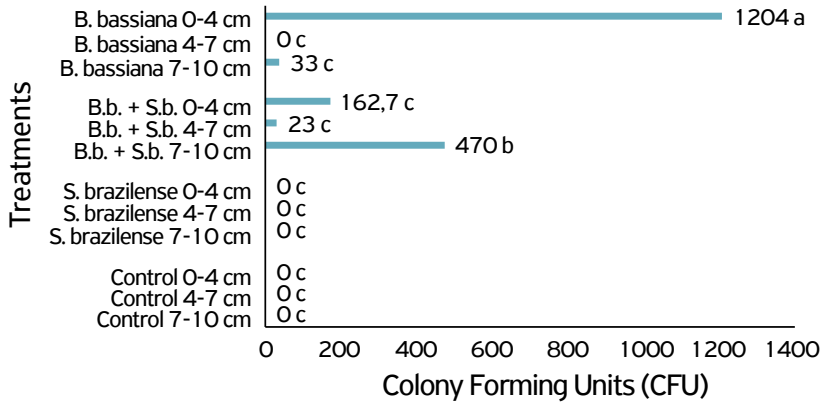

Trial 4

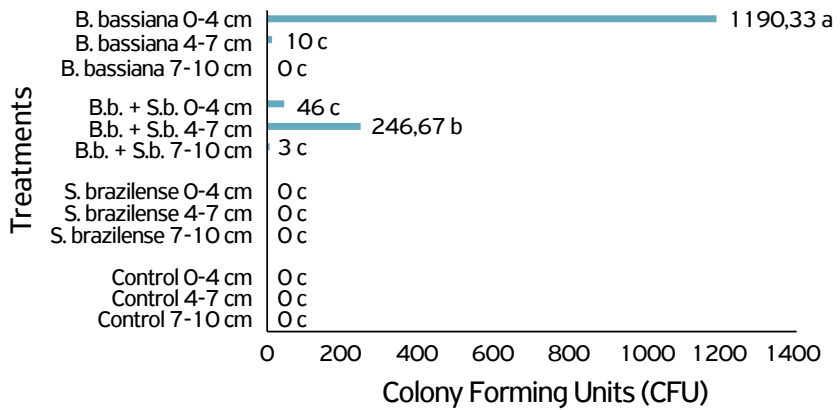

Figure 1. Conidia carriage trials in different depths of sandy soil after application of Beauveria bassiana, Steinernema brazilense, the combination of B. bassiana with S. brazilense (B.b. + S.b.), and control (water) in four repeated trials. Means followed by the same letter do not differ from each other by the Duncan test at $5 \%$ probability. 
Conversely, in silt-clay soil, $90 \%$ of the conidia were found in the $2 \mathrm{~cm}$ superficial layer. These results show that sandy soils are more propitious to the vertical carriage of conidia.

In the present study, the high concentration of conidia observed at the deepest depths with the $B$. bassiana + S. brazilense combination indicates that the nematode plays an important role in the vertical movement of the conidia, especially in the absence of large volumes of rain water. Working with commercial formulations of $B$. bassiana, STOREY; GARDNER (1987) applied conidia suspended in water in columns of $30 \mathrm{~cm}$ soil and observed downward movement up to $15 \mathrm{~cm}$ deep. According to STOREY; GARDNER (1988), pure B. bassiana conidia sprayed on the soil with a small volume of water were found in the most superficial layer, up to $5 \mathrm{~cm}$, in both sandy and more clayey soils.

The percolation of conidia in the soil was verified in studies carried out by SALAZAR et al. (2007) with the fungus M. anisopliae. Those authors noted that percolation occurred up to depths of $15 \mathrm{~cm}$ in sandy soil. However, in that test, a volume of water was applied for soil saturation, which favored percolation. In the present study, M. anisopliae was only found in the soil surface, probably because of the smaller volume of water used and the smaller pores of the fine sand compared to that used by SALAZAR et al. (2007). When comparing $M$. anisopliae and $B$. bassiana, the higher percolation of $B$. bassiana is probably due to the smaller size of its conidia compared with $M$. anisopliae.

Trial 1

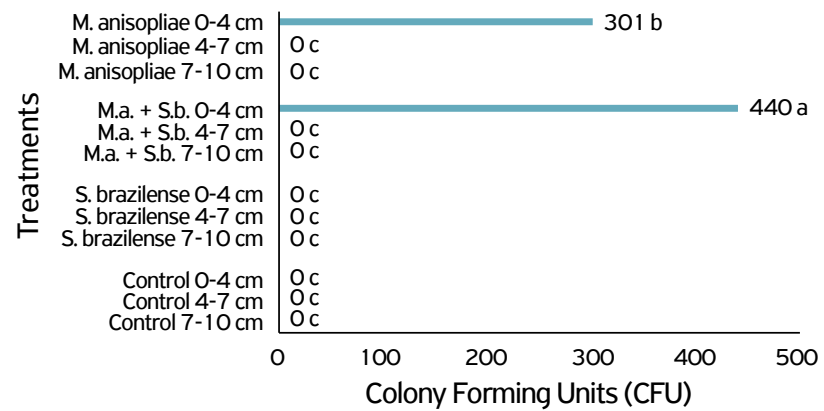

Trial 3

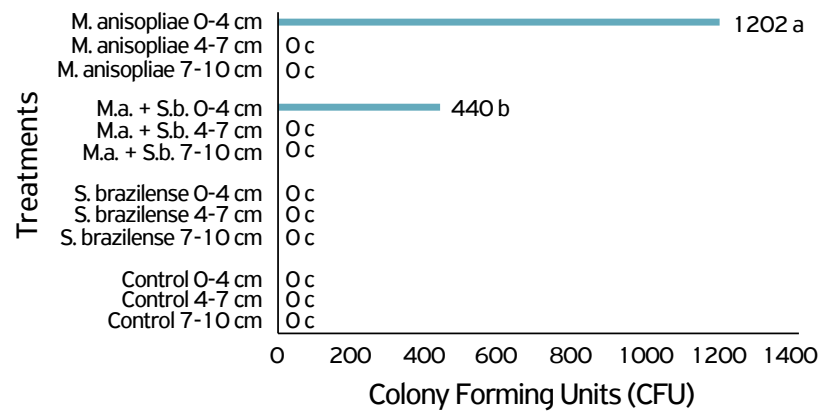

More recently, greenhouse studies have shown phoresis between the nematode $S$. carpocapsae and the fungus B. bassiana with Lumbricus terrestris earthworms (Linnaeus, 1758) (Haplotaxida: Lumbricidae), with a better dispersion and higher performance of the entomopathogens on larvae of Curculio caryae (Latrille, 1802) (Coleoptera: Curculionidae) in the presence of the annelid. Thus, the presence of the earthworm and other phoretic agents contribute to the dispersion of the conidia and infective juveniles in the soil layers (SHAPIRO-ILAN; BROWN, 2013).

The results of the present study suggest that the nematode S. brazilense can assist in the vertical carriage of $B$. bassiana conidia to deeper layers of the soil, contributing to a higher deposition of the fungus on the insect and, consequently, to a higher insect mortality due to the fungus + nematode effect or synergistic actions of the two agents.

Entomopathogenic fungi depend on direct contact with an insect for infection (ALVES, 1998), and therefore, are more commonly used to control pests in the aerial part or on the soil surface, since for the control of subterranean pests, the soil may represent a barrier for conidia movement and contact with the host. Thus, their application in combination with nematodes can extend the movement of the conidia to greater soil depths with greater chances of reaching the host. In addition, this enables the potentiation of nematode virulence by debilitating the insect , making it more susceptible to this agent. When the fungus penetrates the insect, a series of processes occur that activate the
Trial 2

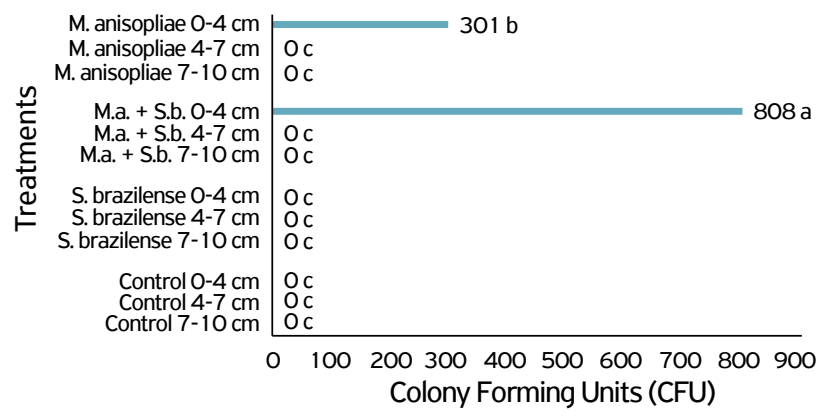

Trial 4

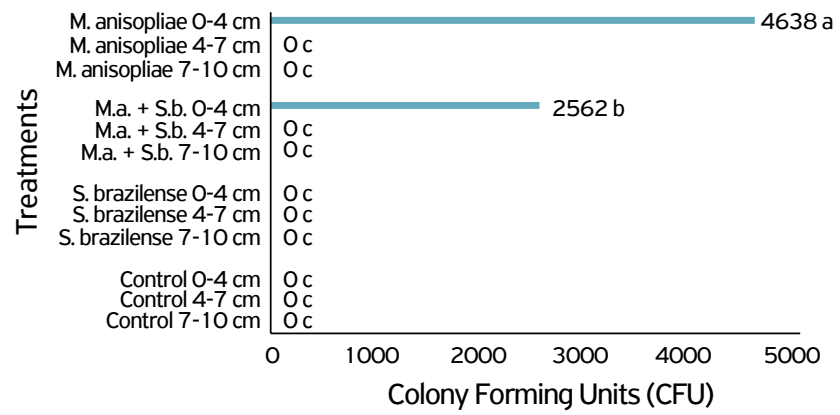

Figure 2. Conidia carriage trials in different depths of sandy soil after application of Metarhizium anisopliae, Steinernema brazilense, the combination of M. anisopliae with S. brazilense (M.a. + S.b.), and control (water) in four repeated trials. Means followed by the same letter do not differ from each other by the Duncan test at $5 \%$ probability. 
defense bodies in the host's hemolymph. When high concentrations of conidia reach the insect, they are able to penetrate the cuticle, overloading the host's defenses and leaving it more susceptible to the nematode, which can induce death and reduce populations faster than the application of either agent alone (WILSON et al., 2001).

\section{Effect of S. brazilense and \\ B. bassiana on the mortality of $C$. humeropictus in the field}

All treatments combining nematode + fungus had an additive effect on mortality, but no significant differences were found compared with the fungus and nematode tested alone (Fig. 3 and Table 3). The treatments resulting in the highest mortality rates were $S$. brazilense $\left(9 \mathrm{IJ} / \mathrm{cm}^{2}\right)+B$. bassiana; $S$. brazilense $\left(27 \mathrm{IJ} / \mathrm{cm}^{2}\right)+$ B. bassiana; and S. brazilense $\left(27 \mathrm{IJ} / \mathrm{cm}^{2}\right)$, which differed significantly only compared with the fungus alone and the control $(\mathrm{F}=2.790 ; \mathrm{p}=0.027)$.

The levels of control obtained following application of the nematode alone did not exceed $60 \%$ at a dose of $27 \mathrm{IJ} \mathrm{cm}^{2}$, suggesting that further studies are needed to identify more virulent nematodes for the larval stage of the insect. Nematode alone at the lowest dose caused 33.3\% insect mortality and the fungus $(10 \mathrm{~kg} / \mathrm{ha})$ caused $15.6 \%$ mortality, although there was no significant difference between these treatments (Table 3).

The combination of $S$. brazilense and B. bassiana led to an increase in insect mortality of up to $15.6 \%$ when compared with the respective treatment of the nematode tested

Nematode

Nematode + Fungus $(10 \mathrm{Kg} / \mathrm{ha})$

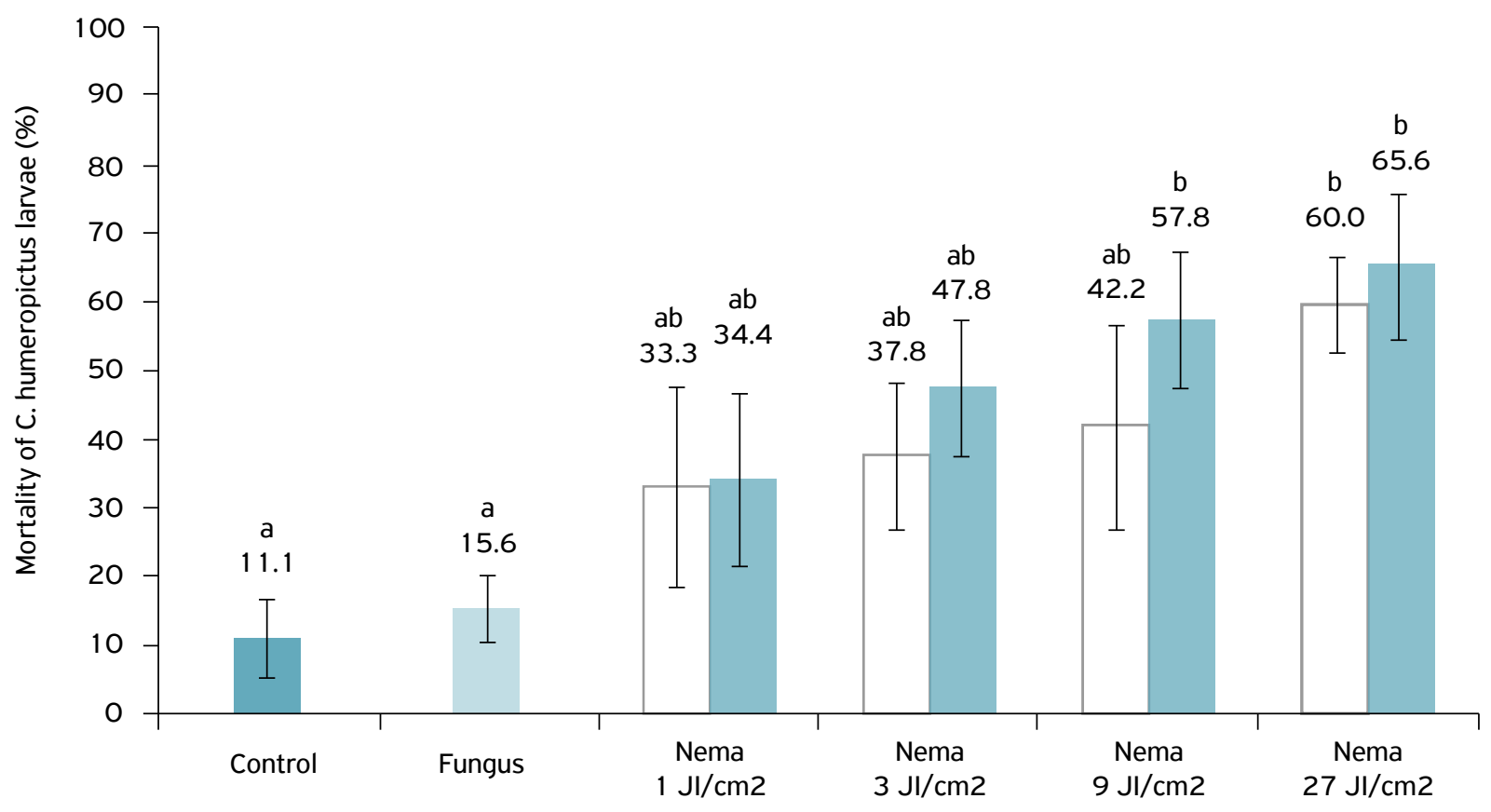

Treatments

Figure 3. Mortality of Conotrachelus humeropictus larvae exposed to the Steinernema brazilense nematode at doses of $1,3,9$ and $27 \mathrm{IJ} / \mathrm{cm}^{2}\left(1,3,9\right.$, and $\left.27 \times 10^{8} \mathrm{IJ} / \mathrm{ha}\right)$, tested alone and combined with the fungus Beauveria bassiana at a dose of $10 \mathrm{~kg} / \mathrm{ha}$.

Table 3. Interaction between Steinernema brazilense and Beauveria bassiana applied in the field to control larvae of Conotrachelus humeropictus.

\begin{tabular}{lcccc} 
Treatment & $\mathrm{M}_{\mathrm{O}}{ }^{1}(\%)$ & $\mathrm{M}_{\mathrm{E}}{ }^{2}(\%)$ & $\mathrm{x}^{2}$ & \multicolumn{2}{c}{ Interaction Type $^{3}$} \\
\hline S. brazilense $1 \mathrm{IJ} / \mathrm{cm}^{2}+$ B. bassiana & 34.4 & 43.70 & 1.97 & additive \\
\hline S. brazilense $3 \mathrm{IJ} / \mathrm{cm}^{2}+$ B. bassiana & 47.8 & 47.50 & 0.01 & additive \\
\hline S. brazilense $9 \mathrm{IJ} / \mathrm{cm}^{2}+$ B. bassiana & 57.8 & 64.38 & 0.67 & additive \\
\hline S. brazilense $27 \mathrm{IJ} / \mathrm{cm}^{2}+$ B. bassiana & 65.6 & 70.97 & 0.41 & additive
\end{tabular}

'Mo: Mortality observed and confirmed.

${ }^{2} \mathrm{M}_{\mathrm{E}}$ : Mortality expected $=\mathrm{M}_{\mathrm{Nema}}+\mathrm{M}_{\text {Fungus }}\left(1-\mathrm{M}_{\mathrm{Nema}}\right)$, where $\mathrm{M}_{\mathrm{Nema}}$ and $\mathrm{M}_{\text {Fungus }}$ are, respectively, the observed proportional mortalities caused by the nematode and the fungus applied alone.

${ }^{3}$ Interactions based on the $\mathrm{x}^{2}$ ratio of mortality expected:observed. 
alone at $9 \mathrm{IJ} / \mathrm{cm}^{2}$, which had an additive effect. However, the combination of this nematode with this $B$. bassiana isolate may not be the optimal choice, because of the high dose of fungus used (10 kg/ha).

Many studies have evaluated the combined use of nematodes and entomopathogenic fungi with additive or synergistic effects on insect mortality (ANSARI et al., 2006; ACEVEDO et al., 2007; SHAPIRO-ILAN et al., 2004; ANSARI et al., 2008). In general, the combined use of these agents increases mortality, but may negatively affect entomopathogen reproduction by reducing the production of IJs or conidia (ACEVEDO et al., 1997).

It is possible that the increased mortality is caused by the stress imposed on the insect in the presence of two or more natural enemies. A stressor such as an entomopathogenic fungus or nematode can weaken the target insect and increase its susceptibility to a second control agent. This can increase pest control or reduce the lethal time (LT). This eventually leads to an additive or synergistic effect resulting from the combined application of multiple control agents (SHAOHUI et al., 2014).

In addition to the increased mortality rate, accelerated pest mortality is another advantage of the combined use of agents. TARASCO et al. (2011) verified that the combined application of $B$. bassiana + Heterorhabditis heliothidis can reduce the host's LT.

Additive effects were reported by SHAPIRO-ILAN et al. (2004) in studies with Curculio caryae (Horn, 1873) (Coleoptera: Curculionidae) following the application of the fungus $M$. anisopliae and the nematode $H$. indica. However, they reported adverse effects with the combined application of $B$. bassiana and $H$. indica, $H$. indica + Isaria fumosorosea, S. carpocapsae + I. fumosorosea, as well as with the combination of the bacterium Serratia marcescens with S. carpocapsae and with $H$. indica.

Antimicrobial compounds can be released by both entomopathogenic fungi and symbiotic bacteria of entomopathogenic nematodes (TARASCO et al., 2011). Thus, some strategies demonstrate that the application of nematode and fungus at different times can promote a synergistic effect in pest control (ANSARI et al., 2004; ANBESSE et al., 2008).

In the present study, the combined application of $S$. brazilense + B. bassiana caused additive effects on C. humeropictus mortality. Further studies should aim to apply these agents at different times, which should also include other species of nematodes. The combination of entomopathogenic nematodes and the fungus $M$. anisopliae should also be evaluated, since this pathogen is most frequently found on larvae of $C$. humeropictus under natural field conditions, and because several studies have noted an increase in the mortality of subterranean pests with the combined use of this fungus and entomopathogenic nematodes.

\section{CONCLUSIONS}

IJ of S. brazilense (IBCB n6) applied in combination with a B. bassiana conidia suspension (IBCB 170 isolate) can carry the fungus to deeper layers of sandy soil. The combination of S. brazilense and B. bassiana (IBCB 276) caused an additive effect on the mortality of $C$. humeropictus larvae at all concentrations used.

\section{REFERENCES}

ACEVEDO, J.P.M.; SAMUELS, R.I.; MACHADO, R.I., DOLINSKI, C. Interactions between isolates of the entomopathogenic fungus Metarhizium anisopliae and the entomopathogenic nematode Heterorhabditis bacteriophora JPM4 during infection of the sugar cane borer Diatraea saccharalis (Lepidoptera: Pyralidae). Journal of Invertebrate Pathology, San Diego, v.96, p. 187-192, 2007.

ALVES, S.B. Fungos entomopatogênicos. In: Controle microbiano dos insetos. Piracicaba: FEALQ, 1998. p.289-370.

ANBESSE, S.A.; ADGE, J.B.; GEBRU, W.M. Laboratory screening for virulent entomopathogenic nematodes (Heterorhabditis bacteriophora and Steinernema yirgalamense) and fungi (Metarhizium anisopliae and Beauveria bassiana) and assessment of possible synergistic effects of combined use against grubs of the barley chafer Coptognathus curtipennis. Nematology, Leiden, v.10, n.5, p.701-709, 2008.
ANSARI, M.A.; SHAH, F.A.; BUTT, T.M. Combined use of entomopathogenic nematodes and Metarhizium anisopliae as a new approach for black vine weevil, Otiorhynchus sulcatus, control. Entomologia experimentalis et applicata, Amsterdam, v.129, p.340-347, 2008.

ANSARI, M.A.; TIRRY, L.; MOENS, M. Antagonism between entomopathogenic fungi and bacterial symbionts of entomopathogenic nematodes. Biocontrol, Dordrecht, v.50, p.465-475, 2005.

Interaction between Metarhizium anisopliae CLO 53 and entomopathogenic nematodes for the control of Hoplia philanthus. Biological Control, Orlando, v.31, p.172-180, 2004.

ANSARI, M.A.; SHAH, F.A.; TIRRY, L.; MOENS, M. Field trials against Hoplia philantus (Coleoptera: Scarabaeidae) with a combination of an entomopathogenic nematode and the fungus Metarhizium anisopliae CLO 53. Biological Control, Orlando, v.39, p.453-459, 2006. 
BEDDING, R.A. Low cost in vitro mass production of Neoaplectana and Heterorhabditis species (Nematoda) for field control of insect pests. Nematologica, Leiden, v.27, p.109-114, 1981.

CAMPBELL, J.F.; KAYA, H.K. Influence of insect associated cues on the jumping behavior of entomopathogenic nematodes (Steinernema spp.). Behaviour, Leiden, v. 137, p.591-609, 2000.

DOWDS, B.C.A.; PETERS, A. Virulence Mechanisms. In: GAUGLER, R. (Ed.). Entomopathogenic Nematology. New York: CABI, 2002, p. 79-98.

IGNOFFO, C.M.; GARCIA, C.; HOSTETTER, D.L.; PINELLI, R.E. Vertical movement of conidia of Nomuraea rileyi through sand and loam soils. Journal of Economic Enthomology, Lanham, v.70, n.2, p.163-164, 1977

KAYA, H.K.; GAUGLER, R. Entomopathogenic nematodes. Annual Review of Entomology, Stanford, v.38, p.181-206, 1993. DOI: 10.1146/annurev.en.38.010193.001145

KOPPENHÖFER, A.M.; KAYA, H,K.; Additive and synergistic interaction between entomopathogenic nematodes and Bacillus thuringiensis for scarab grub control. Biological Control, Orlando, v.8, p.131-137, 1997.

LAKER, H.A.; TREVISAN, O. The increasing importance of cupuaçu (Theobroma grandiflorum) (Schum) in the Amazon Region of Brasil. Cocoa Growers Bulletin, Bournville, n.45, p.45-52, 1992.

MENDES, A.C.B.; MAGALHÃES, B.P.; OHASHI, O.S. Biologia de Conotrachelus humeropictus, FIEDLER, 1940 (Coleoptera: Curculionidae), praga do cacaueiro e do cupuaçuzeiro na Amazônia brasileira. Acta Amazônica, Manaus, v.27, n.2, p.135-144, 1997.

SALAZAR, A.M.P.; GERDING, M.G.; FRANCES, A.I.; CAMPOS, J.P.; GERDING, M.P.; SANDOVAL, M.E. Desplazamiento de conidias de Metarhizium anisopliae var. anisopliae em columnas de tres series de suelo. Agricultura Técnica, Santiago de Chile, v.67, n.3, p.236-243, 2007.

SAS INSTITUTE. Statistical Analysis System. Versão 9.0. Cary: SAS Institute, 2000.
SHAOHUI, W.; YOUNGMAN, R.R.; KOK, L.T.; LAUB, C.A., PFEIFFER, D.G. Interaction between entomopathogenic nematodes and entomopathogenic fungi applied to third instar southern masked chafer white grubs, Cyclocephala lurida (Coleoptera: Scarabaeidae), under laboratory and greenhouse conditions. Biological Control, Orlando, v.76, p.65-73, 2014. DOI: 10.1016/j.biocontrol.2014.05.002

SHAPIRO-ILAN, D.; BROWN, I. Earthworms as phoretic hosts for Steinernema carpocapsae and Beauveria bassiana: Implications for enhanced biological control. Biological Control, Orlando, v.66, p.41-48, 2013.

SHAPIRO-ILAN, D.I.; JACKSON, M.; REILLY, C.C.; HOTCHKISS, M.W. Effects of combining an entomopathogenic fungi or bacterium with entomopathogenic nematodes on mortality of Curculio caryae (Coleoptera: Curculionidae). Biological Control, Orlando, v. 30, p.119-126, 2004

STOREY, G.K.; GARDNER, W.A. Vertical movement of commercially formulated Beauveria bassiana conidia through four Georgia soil types. Environmental Entomology, College Park, v.16, p.178-181, 1987.

STOREY, G.K.; GARDNER, W.A. Movement of an aqueous spray of Beauveria bassiana into the profile of four Georgia soils. Environmental Entomology, College Park, v.17, p.135-139, 1988.

THURSTON, G.S.; KAYA, H.K.; GAUGLER, R. Characterizing the enhanced susceptibility of milky disease-infected scarabaeid grubs to entomopathogenic nematodes. Biological Control, Orlando, v.4, p.67-73, 1994.

TREVISAN, O. Manejo Integrado das pragas do cacaueiro na região amazônica: Conotrachelus humeropictus. Folha Técnica Superintendência do Desenvolvimento da Região Cacaueira no Estado do Pará, n. 1, p. 1-2, 2011.

TARASCO, E.; ALVAREZ, C.S.; TRIGGIANI, O.; MORAGA, E.Q. Laboratory studies on the competition for insect haemocoel between Beauveria bassiana and Steinernema ichnusae recovered in the same ecological niche. Biocontrol Science and Technology, Oxford, v.21, n.6, p.693-704, 2011.

WILSON, K.; COTTER, A.C.; REESON, A.F.; PELL, J.K. Melanism and disease resistance in insects. Ecology Letters, Oxford, v.4, n.6, p.637-649, 2001. 